\title{
Research on drug use goes down the toilet
}

$\mathrm{S}$ ewers don't lie. People may be less than forthright about what they put into their bodies, especially if that includes illicit drugs, but a chemical analysis of what comes out of their bodies removes all mystery. According to drug and addiction researchers, analysing wastewater for remnants of illicit substances provides the only truly objective indicator of drug use patterns in a community.

"Whatever you think about drugs, people need to have objective data so they can at least have an informed discussion," says Caleb Banta-Green, a research scientist at the University of Washington's Alcohol and Drug Abuse Institute in Seattle.

In a study of the wastewater in 96 municipalities in Oregon, Banta-Green and colleagues collected data on the presence of drugs such as cocaine and methamphetamine (Addiction 2009;104: 1874-80). They found that cocaine use was much higher in cities, whereas methamphetamine was popular in all areas. Wastewater testing was a promising drug surveillance tool, one that could help communities better combat their drug problems, the paper concluded. "Data on drug index loads are of value for planning local drug prevention, intervention and treatment efforts at a much smaller geographic level and with better timeliness than was possible previously."

Traditionally, the amount of illegal drugs consumed at the community level is estimated from sources such as surveys, police data and information from emergency departments and morgues. Often, however, this information is rife with bias and tells only part of the story.

Surveys miss certain segments of the population, such as inmates, and are prone to self-report bias because of the stigma of illegal drug use. There is detection bias in police data because drugs such as crack cocaine, often used on the street, result in more arrests than drugs such as powder cocaine, which is more commonly found at private parties. As for hospital data, a death attributed to a traffic accident might actually be a death due to the drug abuse that led to the accident.

Sewage epidemiology is also less expensive than a survey and, unlike existing surveillance tools, can provide real-time data on community drug patterns. If a community implements a new intervention program, for example, or if several major drug dealers are arrested, any ensuing drop in drug use could be detected. "Drug use can change dramatically over a short period," says Banta-Green.

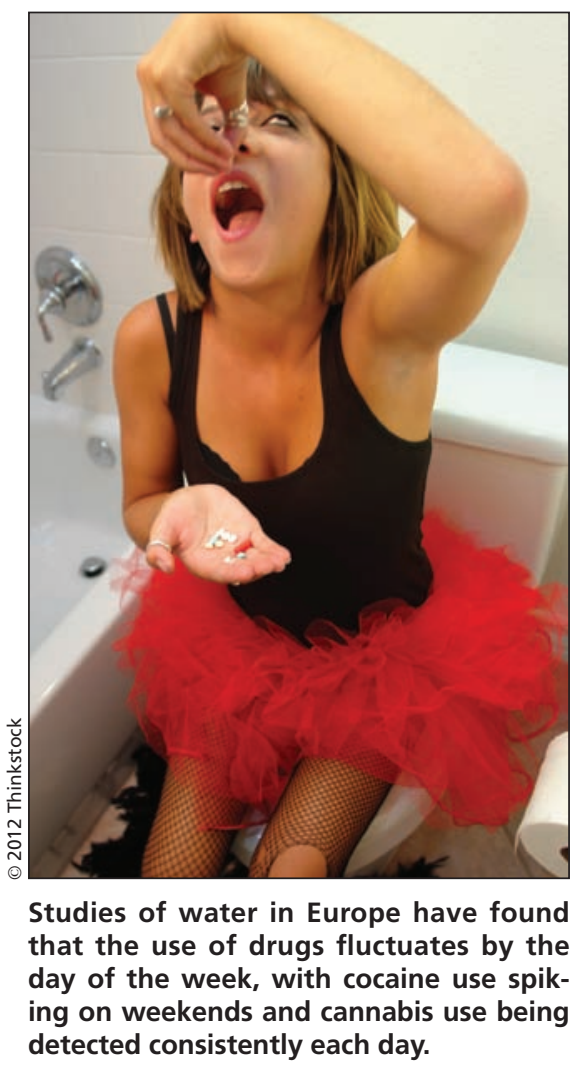

These advantages have led to a spike in interest in sewage epidemiology in some countries, including Wales, Ireland and other parts of Europe. One study, conducted on wastewater in Italy, Switzerland and the United Kingdom, found that the use of certain drugs fluctuates throughout the week (Environ Health Perspect 2008;116:1027-32). Cocaine use shot up on weekends, for instance, though cannabis was detected consistently each day.

The information culled from wastewater can be combined with other data on drugs to refine a community's drug profile, the study states: "If applied to other public health issues, this approach has the potential to extract useful epidemiologic data from qualitative and quantitative profiling of biological indicators entering the sewage system."

The advantages of monitoring drug use via wastewater analysis include time and money savings, the removal of bias and, because data is collected at the community level, the absence of privacy issues, according to the European Monitoring Centre for Drugs and Drug Addiction (www.emcdda.europa.eu /attachements.cfm/att_139185_EN_emc dda-insights-wastewater.pdf). Disadvantages include the inability to determine if drug patterns change because more people are using drugs or because existing users are consuming more drugs, restrictions on access to water systems and the negative effect of heavy rainfall on accurate data collection.

Unlike in Europe, little research on illicit drug residue in wastewater has been done in Canada or the United States. "This is a bit puzzling because the technique is being applied widely in Europe. However, here in Canada it seems that this work falls into the cracks between the mandates of various government agencies," Chris Metcalfe, professor of environmental and resource studies at Trent University in Peterborough, Ontario, writes in an email.

"All representatives that we talk to are fascinated by the research, but find it difficult to get their heads around how the work can help them with their mandate," adds Metcalfe.

Indeed, government agencies tend to focus on drinking water, not pretreated waste water, which researchers in sewage epidemiology use because many of the remnants of illicit drugs are filtered out during treatment, leaving levels that aren't harmful. "Health Canada and other jurisdictions focus on testing source water and treated drinking water, rather than wastewater,' Gary Holub, Health Canada media relations officer, writes in an email. "This provides a more accurate assessment of potential pharmaceutical exposures and any associated health risks."

This is also the case in the US. Because there is no great environmental threat, US governing bodies aren't that worried about illicit drugs in the water, according to Banta-Green. If a chemical in the water isn't killing fish or "giving 
them extra eyeballs," it raises few alarms, he suggests. It also doesn't help that drug abuse is largely viewed as a legal problem in the US rather than a health problem, writes Banta-Green: "Here, you get these very reactionary responses to anything around drug abuse. There is a whole moralistic tone to it."

The odds of wastewater testing becoming a more common screening tool will likely increase once researchers refine the technique, Viviane Yargeau, associate professor of chemical engineering at McGill University in Montréal, Quebec, writes in an email. "There are still some uncertainties related to this sewage epidemiology approach, mainly associated with the not entirely understood fate of drugs and their metabolites in sewers, and the varying and not well understood excretion profiles of drugs, which might be dependent on disease, drug interactions, ethnic differences, sex, age and lifestyle. These uncertainties need to be resolved before this tool is implemented as a routine community screening technique for drug use." Roger Collier, CMAJ

CMAJ 2012. DOI:10.1503/cmaj.109-4082

\section{More news online}

Physicians must be brought up to speed on concussion risks: (www.cmaj .ca/lookup/doi/10.1503/cmaj.109-4080). — Jordan Fallis, Ottawa, Ont.

Promise of nano revolution hasn't materialized: (www.cmaj.ca/lookup/doi /10.1503/cmaj.109-4068). - Sabrina Doyle, Ottawa, Ont.

Public health fallout from Japanese quake: (www.cmaj.ca/lookup/doi /10.1503/cmaj.109-4083). — Lauren Vogel, CMAJ

Reducing the "pill burden": (www.cmaj.ca/lookup/doi/10.1503/cmaj .109-4076). — Roger Collier, CMAJ

Prices gone wild: Grey market 'scalpers' scoring windfall in American drug market: (www.cmaj.ca/lookup/doi/10.1503/cmaj.109-4081). - Cal Woodward, Washington, DC

Stem cell tourism poses risks: (www.cmaj.ca/lookup/doi/10.1503/cmaj .109-4073). - Carolyn Brown, Ottawa, Ont.

Crowdfunding for medical expenses: (www.cmaj.ca/lookup/doi/10.1503 /cmaj.109-4084). - Julia Sisler, Ottawa, Ont.

Universal health coverage still rare in Africa: (www.cmaj.ca/lookup /doi/10.1503/cmaj.109-4052). - Bernard Appiah, College Station, Tex.

Pfizer advertises smoking cessation drug despite health warnings: (www.cmaj.ca/lookup/doi/10.1503/cmaj.109-4087). — Laura Eggertson, Ottawa, Ont.

Teaming up to make meaningful use of electronic health records: (www.cmaj.ca/lookup/doi/10.1503/cmaj.109-4090). - Kayla Redstone, Ottawa, Ont.

Tracking opioid use vital to avoiding scourge: (www.cmaj.ca /lookup/doi/10.1503/cmaj.109-4085). - Paul Christopher Webster, Toronto, Ont.

CMAJ 2012. DOI:10.1503/cmaj.109-4092 